\title{
Preserving the World Second Largest Hypersaline Lake under Future Irrigation and Climate Change
}

\author{
Somayeh Shadkam ${ }^{1}$, Fulco Ludwig ${ }^{1}$, Michelle T.H. van Vliet ${ }^{1,2}$, Amandine Pastor ${ }^{1,2}$, \\ Pavel Kabat ${ }^{1,2}$
}

[1] Earth System Science, Wageningen University, PO Box 47, 6700 AA Wageningen, The Netherlands

[2] International Institute for Applied Systems Analysis (IIASA), Schlossplatz 1, A-2361

Laxenburg, Austria

E-mail: somayeh.shadkam@wur.nl

\begin{abstract}
Urmia Lake, the world second largest hypersaline lake, has been largely desiccated over the last two decades resulting in socio-environmental consequences similar or even larger than the Aral Sea disaster. To rescue the lake a new water management plan has been proposed, a rapid $40 \%$ decline in irrigation water use replacing a former plan which intended to develop reservoirs and irrigation. However, none of these water management plans, which have large socio-economic impacts, have been assessed under future changes in climate and water availability. By adapting a method of environmental flow requirements (EFRs) for hypersaline lakes, we estimated annually $3.7 \cdot 10^{9} \mathrm{~m}^{3}$ water is needed to preserve Urmia Lake. Then, the Variable Infiltration Capacity (VIC) hydrological model was forced with bias-corrected climate model outputs for both the lowest (RCP2.6) and highest (RCP8.5) greenhouse-gas concentration scenarios to estimate future water availability and impacts of water management strategies. Results showed a $10 \%$ decline in future water availability in the basin under RCP2.6 and 27\% under RCP8.5. Our results showed that if future climate change is highly limited (RCP2.6) inflow can be just enough to meet the EFRs by implementing the reduction irrigation plan. However, under more rapid climate change scenario (RCP8.5) reducing irrigation water use will not be enough to save the lake and more drastic measures are needed. Our results showed that future water management plans are not robust under climate change in this region. Therefore, an integrated approach of future land-water use planning and climate change adaptation is therefore needed to improve future water security and to reduce the desiccating of this hypersaline lake.
\end{abstract}

Keywords: Urmia Lake, Hypersaline Lake, Climate Change, Irrigation, Reservoirs, Hydrological Model 


\section{Introduction}

To supply food and energy for growing populations, humans have developed reservoirs and extract water for irrigation (Biemans et al. 2011). Furthermore, climate change has a significant impact on the natural hydrological cycle and amplifies water scarcity in (semi)-arid regions (Haddeland et al. 2014). Consequently, managing water for a growing population without harming natural resources is becoming a serious challenge. In this paper, we assess this challenge in Urmia basin, where the second largest permanent hypersaline lake in the world is drying up (Karbassi et al. 2010).

Urmia Lake, in north-western Iran, is an important internationally recognized natural area designated as a RAMSAR site and UNESCO Biosphere Reserve (Eimanifar and Mohebbi 2007). It is a home to many species of reptiles, amphibians and mammals along with a unique brine shrimp species (Asem et al. 2012). Urmia Basin supports a variety of agricultural production systems and activities as well as livestock. The basin is located in a politically tensed region bordering both Iraq and Turkey. It is linguistically and culturally diverse area dominated by two ethnic groups, Azeri Turks and Kurdish (Henareh et al. 2014).

Over the last 40 years, the water level and surface area of Urmia lake have declined (Rokni et al. 2015) by $80 \%$ (AghaKouchak et al. 2015). As a result, the salinity of the lake has sharply increased which is disturbing the ecosystems, local agriculture and livelihoods, regional health, as well as tourism. (UNEP 2012). Several studies have warned that the future of lake Urmia could become similar to the Aral Sea, which has dried up over the past several decades and severely affected the surrounding people with windblown salt storms (Torabian 2015). The population around Urmia Lake, however, is much denser compared to the Aral Sea and many more people are at risk (UNEP 2012). Local reports have indicated that thousands of people around the lake have already abandoned the area (RadioFarda 2014). It has been estimated that 75 million people living within $500 \mathrm{~km}^{2}$ of the Lake location, are at risk (Torabian 2015), which could amplify economic, political and ethnic tensions in this already volatile region (Henareh et al. 2014).

Previous studies have indicated that the lake desiccation is probably caused by a combination of human activities and climate change (AghaKouchak et al. 2015, Fathian et al. 2014, Hamzekhani et al. 2015, Hassanzadeh 2010, Jalili et al. 2015). The area of the agricultural lands has more than tripled over the last 40 years supported by a considerable number of reservoirs and a large irrigation network (Iran Ministry of Energy 2014). There has also been a significant decrease in precipitation and an increasing trend in average maximum temperature during the same period (Delju et al. 2013, Fathian et al. 2014). This has caused the most extreme droughts in the basin over the last few decades during the mid-1990s (Tabari et al. 2013). These trends have affected the inflow into the lake (Fathian et al. 2014) which has been recognized as the main reason of the lake shrinkage (Hassanzadeh et al. 2012). Some studies have estimated how much water is needed to restore (Golabian 2011) and protect the ecology, water quality and quantity of the lake (Abbaspour and Nazaridoust 2007). However, they have not included the important role of climate change which is likely to reduce the precipitation and run-off in both near-term (Kirtman 2013) and long-term future (Collins 2013).

To secure enough food and income for a growing population in the basin, the initial government water resources plan intended to increase the irrigated area by $25 \%$ supported by additional dams and reservoirs. More recently, a new plan has been proposed aiming to restore and preserve Urmia Lake. This plan proposes to stop all reservoir developments and reduces irrigation water allocation by $40 \%$. However, it is still unclear if the water use reduction plan, which is about to start and has large socioeconomic impacts, is able to restore and preserve the lake under future climate change.

The main objective of this study was to assess the impacts of future water resources management plans under climate change on the water inflow into Urmia Lake during the $21^{\text {st }}$ century. To address this objective we first developed a method to estimate the annual and monthly environmental flow requirement (EFRs) to preserve vulnerable hypersaline lake ecosystems especially in a lack of precise ecological data. By applying the method, we quantified how much water is needed to preserve Urmia 
Hypersaline Lake. Then, we developed future projections of total inflow into the lake, using the Variable Infiltration Capacity (VIC) hydrological model (Liang et al. 1994), including an irrigation and reservoir module (Haddeland 2006, Haddeland et al. 2006). The model was forced with statistically bias-corrected General Circulation Models (GCMs) outputs from a low and high representative concentration pathways (RCPs) (Moss et al. 2010). In addition, to study the impact of the water resources plans on the future inflow, the two proposed plans plus the current, and the naturalized (without any irrigation and reservoirs) situations were applied in the model. The simulated inflow was compared with the annual and monthly estimated EFRs to assess the possibilities of Urmia lake restoration and preservation under different climate change and anthropogenic scenarios.

\section{Study area}

Urmia Lake is formed in a natural depression at the lowest point within the closed Urmia basin. The area of the lake has reduced from $\sim 6100 \mathrm{~km}^{2}$ in 1995 to $\sim 1500 \mathrm{~km}^{2}$ in 2014 (figure 1) followed by more than $7 \mathrm{~m}$ decline in the water level (Supplementary information S1). The lake is relatively shallow (maximum depth $16 \mathrm{~m}$ ) and thus vulnerable to evaporation (Meijer et al. 2012). There are 17 permanent rivers and 12 seasonal rivers which terminate at Urmia Lake. The average inflow into the lake has declined from around 12,000 to $2,400 \cdot 10^{6} \mathrm{~m}^{3}$ over the last four decades (Hamzekhani et al. 2015). The mean annual precipitation is $341 \mathrm{~mm} \mathrm{year}^{-1}$ which has decreased by $9.2 \%$ over the last 40 years (Delju et al. 2013).

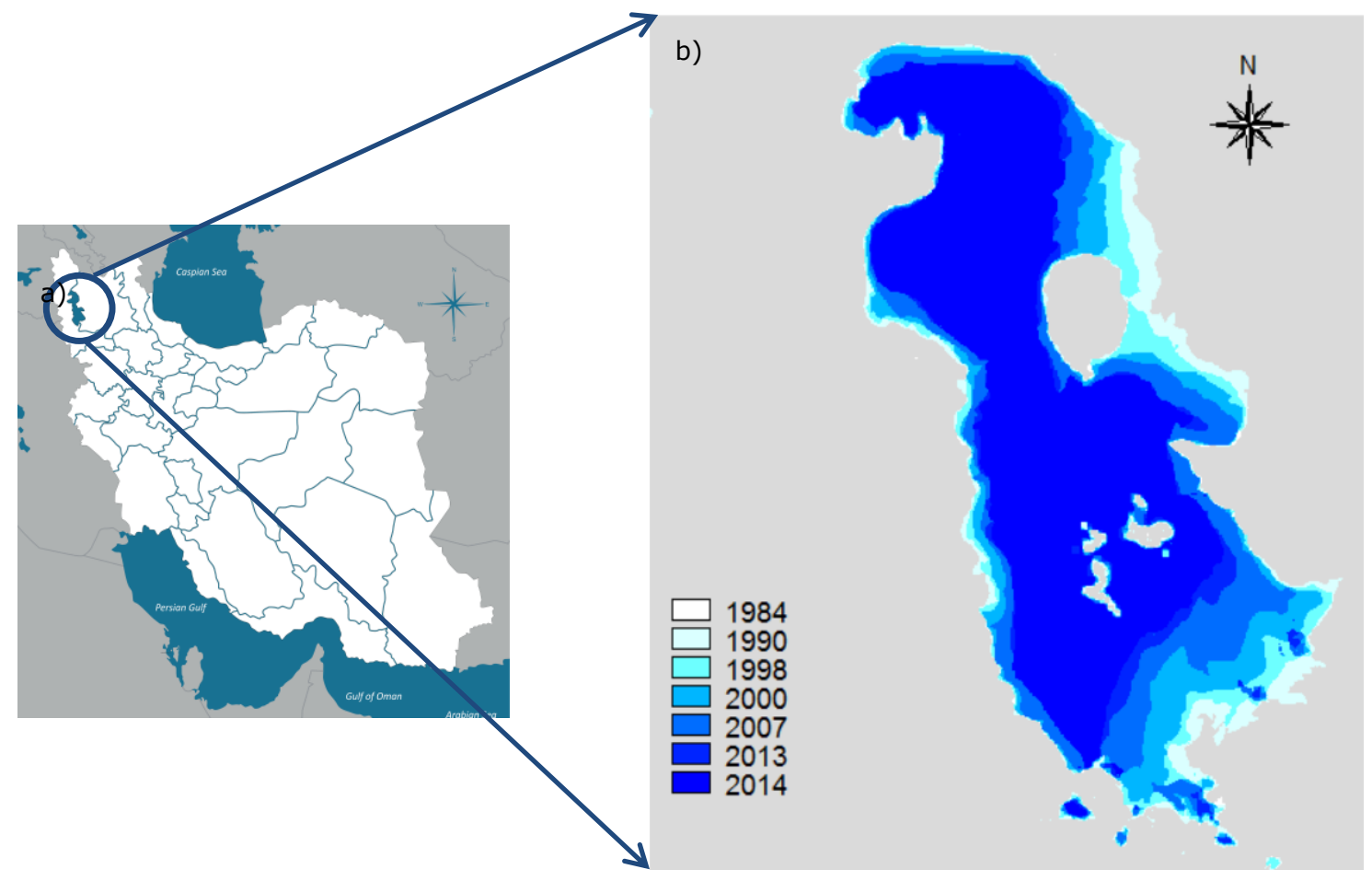

Figure 1 Urmia basin location (a) and the surface area changes from 1984 to 2014, derived from LandSat imagery (b) 


\section{Materials and methods}

The methodological framework for this study is shown in figure 2. Future scenarios for daily flow into the lake were calculated using the VIC hydrological model forced by bias-corrected outputs from five GCMs, using the representative concentration pathway (RCP) 2.6, lowest; (Van Vuuren et al. 2011) and 8.5, highest; (Riahi et al. 2011), for 2010-2099 and for 1971-2000 (control) in combination with four different anthropogenic scenarios (40 simulations). Historical naturalized inflow from the control period was used to estimate annual and monthly environmental flow requirements (EFRs). To assess the significant impact of water resources plans and the climate change impact, the paired two-tailed Student's t-test was used, $\mathrm{P}$ values of $<0.05$ were considered significant.

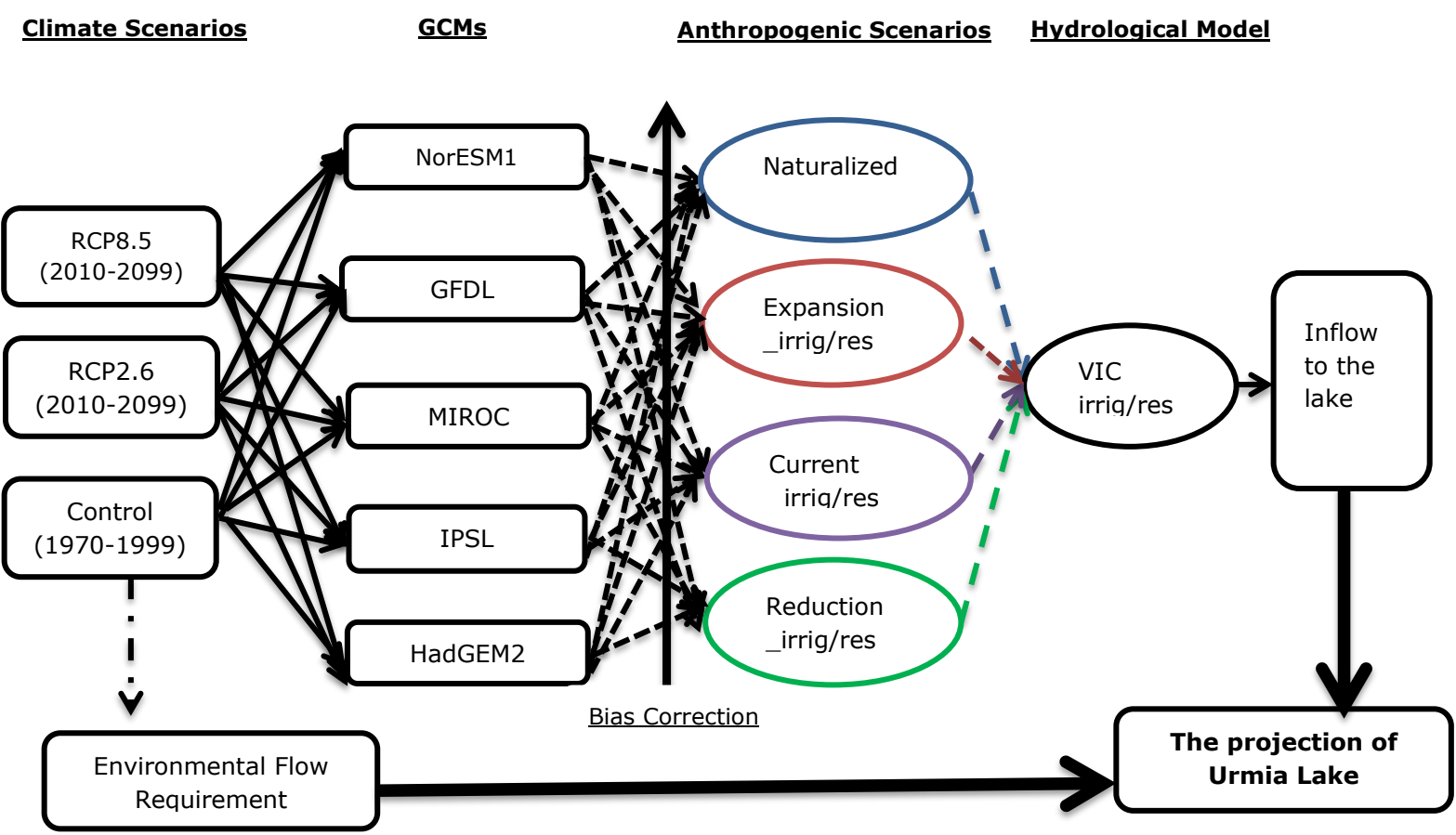

Figure 2 Schematic representation of the modelling framework

\subsection{Hydrological model}

The VIC model is a grid-based soil-vegetation-atmosphere transfer schemes model (Liang et al. 1994, Nijssen et al. 1997, Nijssen et al. 2001b). The input data are daily precipitation, maximum and minimum temperature and wind speed. Each grid cell is divided into multiple vegetation types and into multiple soil layers. Evapotranspiration is calculated using the Penman-Monteith equation. The simulated surface streamflow and baseflow, combined referred as inflow in this paper, are routed from each grid cell to the basin as described by Lohmann et al. (Lohmann et al. 1998a, Lohmann et al. 1998b). The VIC model, like most land surface models, does not consider deep groundwater withdrawals (Haddeland et al. 2007), which therefore are not taken into account in this study. The model has been widely used for streamflow studies globally (Nijssen et al. 2001a, Vliet et al. 2013) and for major river basins, as well as for other basins of the world like Europe, the US, and China (Hurkmans et al. 2008, Vliet et al. 2012, Wu et al. 2007, Xie et al. 2007). The results of these studies have shown that the model has been able to reproduce the water cycle well. 
Haddeland et al. (2006) added reservoirs and irrigation schemes to the VIC model. Therefore, the model simulates irrigation water use, based on the calculated soil moisture deficit. The crop evapotranspiration is first calculated within the grid cells based on FAO's guideline (Allen et al. 1998). The grid cells are divided into an irrigated and a non-irrigated area. In the model, irrigation is initiated if soil moisture falls below the transpiration level. To calculate irrigated water demand, an initial model run is performed assuming irrigation water is freely available (free irrigation run). Then, another simulation run is performed where irrigation is limited by water available from the first local river runoff, and, if no runoff water is available, water is extracted from reservoirs (Haddeland et al., 2006). The reservoir scheme calculates optimal release based on simulated reservoir inflow, storage capacity, reservoir evaporation, and downstream water demands. The optimal released calculated based on the SCEM-UA algorithm (Vrugt et al. 2003). The model was able to simulate well the main hydrologic impacts of reservoir operations and irrigation water withdrawals on streamflow in different parts of the world (Haddeland et al. 2014, Haddeland et al. 2006).

Shadkam et al. (under revision) calibrated the VIC model in a manual, systematic way as described by Xie et al. (2007b), using seven runoff-related model parameters, including the infiltration parameter, and the three soil-layer thicknesses for Urmia basin. They adjusted the model for the Urmia basin by including local information on the elevation, soil, irrigation and reservoir characteristics. They performed a calibration of the model for the basin by dividing the basin to six sub-basins. Results showed that despite the basin's complex topography and semi-arid climate, the VIC-reservoir and irrigation model was able to simulate the streamflow realistically for the all sub-basins (Supplementary information 3).

\subsection{Environmental flow requirements (EFRs)}

Hypersaline lakes, mostly located in semi-arid area, provide a fragile environment which requirements more protection to avoid the extinction of highly adapted species, in dry months in particular (Hammer 1986, Williams 2002). Considering that, we selected the Variable Monthly Flow (VMF) method developed by Pastor et al. (2014) which uses algorithms to classify the flow regime into high, intermediate, and low-flow months and takes intra-annual variability into account by allocating EFRs with a percentage of mean monthly flow (MMF). The method increases the protection of river ecosystems during the low-flow season allocating $60 \%$ of the MMF to $30 \%$ of MMF during the highflow season. The VMF method showed a better performance compared with other three widely used hydrological methods; Tennant et al. (1976), Smakhtin et al. (2004) and Tessmann (1980), to estimate EFRs for semi-arid river basins around the globe including one of the main river in Urmia basin, Shahr-Chai River (Pastor et al. 2014). However, the VMF method was designed to achieve a "fair" ecological status for river flows which does not take into account the high vulnerabilities of hypersaline lakes. Smakhtin et al. (2006), suggested a threshold of one standard deviation (SD) from the mean value of used variable in EFRs estimation for setting environmental flow targets in order to achieve high ecological protection of critical water resources, especially in the absence of other supporting ecological information. Therefore, we adapted the VMF method and increase the EFRs during all months by one SD of the MMF. For Urmia Lake, the MMF was calculated based on monthly average naturalized inflow for 1971-1990; a time period when the size of the lake was relatively stable (Supplementary information S1). Based on this we estimated hypersaline lakes EFRs for different months of the year based on the flow regime according to the equations below:

For low flow months $(M M F \leq 40 \% M A F)$ :

$E F R s=60 \% M M F+S D(M M F)$

$>$ For intermediate flow months $(M M F>40 \% M A F$ and $M M F \leq 80 \% M A F)$ :

$E F R s=45 \% M M F+S D(M M F)$

For high flow months $(M M F>80 \% M A F)$ :

$E F R s=30 \% M M F+S D(M M F)$ 
Where: $E F R s=$ Environmental Flow Requirement $\left[\mathrm{m}^{3} \mathrm{~s}^{-1}\right] ; M M F=$ Mean Monthly Flows $\left[\mathrm{m}^{3} \mathrm{~s}^{-1}\right]$ and $M A F=$ Mean Annual Flows $\left[\mathrm{m}^{3} \mathrm{~s}^{-1}\right] ; S D(M M F)=$ one standard deviation of Mean Monthly Flows $\left[\mathrm{m}^{3} \mathrm{~s}^{-1}\right]$

\subsection{Anthropogenic scenarios}

In addition to using naturalized flow ('naturalized'), the first scenario, and a continuation of the current water management ('current_irrig/res'), the second scenario, we applied two additional anthropogenic scenarios based on two recent official water management plans. Therefore, the third scenario assumes an expansion of the dams and reservoirs ('expansion_irrig/res') to increase irrigation and food production. The expansion_irrig/res scenario is based on the initial government's plan to develop reservoirs and irrigation in the basin. In this plan, there are around 68 dams and reservoirs in construction or in design phases. The proposed projects that are in a construction phase regulate $1212 \cdot 10^{6} \mathrm{~m}^{3}$ water and those which are in a design phase regulate $657 \cdot 10^{6} \mathrm{~m}^{3}$ water. Therefore, total volume of the reservoir will become $3869 \cdot 10^{6} \mathrm{~m}^{3}$ in nearly 20 years (Supplementary Information S2). This will support an additional 130,000 ha. of irrigated land (25\% increase). The reservoirs characteristics including height, storage capacity, operating purpose, irrigating area and surface area, were added to the reservoirs scheme of the model. Furthermore, the irrigated lands characteristics including percentage irrgated area, crop characteristics for each cell, and the cropping calendar added to the irrigation scheme (Iran Ministry of Energy 2014). The forth scenario aims at restoring the lake and reduces future irrigation ('reduction_irrig'). In April 2014, the steering committee of the Lake Urmia restoration programme announced the approval of a new water resources management plan. In the new plan all reservoirs and irrigation development will be stopped. In addition, the state will buy $40 \%$ of irrigation water rights and allocate it to the lake (Lake Urmia restoration programme 2014). As it is not clear yet how the plan will be implemented in the basin we evenly decreased $40 \%$ of each irrigated cell from the current situation in order to simulate the reduction_irrig scenario.

\subsection{Climate change scenarios}

Bias-corrected daily climate model output as developed within the Inter-Sectoral Impact Model Intercomparison Project (Hempel et al. 2013, ISI-MIP, Warszawski et al. 2014) were used to force the model. Data from five GCMs; (MIROC-ESM-CHEM, IPSL-CM5A-LR, HadGEM2-ES, NorESM1-M and GFDL-ESM2M) were selected based on availability (Taylor et al. 2012). To cover the whole range of future greenhouse gas emissions we selected the highest (8.5) (Riahi et al. 2011) and the lowest (2.6) (Van Vuuren et al. 2011) RCPs. As GCMs output differs significantly from observations, biascorrected of GCMs output was used to force the VIC hydrological model. Bias-corrections of daily temperature, precipitation, and wind speed were done using quantile mapping (Piani et al. 2010). GCMs projections were simultaneously re-gridded to the $0.5^{\circ} \times 0.5^{\circ}$ grid of the Climatic Research Unit of the University of East Anglia (CRU) and bias-corrected to the reference data set of WATCH Forcing Data (WFD) (Weedon 2011) for the period 1960-1999.

\section{Results}

\subsection{Evaluation of control simulation of river discharge}

Simulated inflows for control period 1971-2000 of five GCMs were compared with those based on the historical WFD also with observed values to evaluate the overall performance of the VIC-irrigation and reservoir model (figure 3). Boxplots for simulated mean annual inflows based on the five GCMs corresponded well with boxplots of the observed values (figure 3). However, the median values are slightly overestimated for MIROC and GFDL and underestimated for HadGEM2 and IPSL compared to observations. The median results derived from NorESM1 were quite similar as the observed inflow. Furthermore, the boxplots of simulated discharge for all GCMs correspond closely with the boxplots 
for WFD, which indicates that there is no distinct impacts of biases in GCMs output on the control inflow simulation.

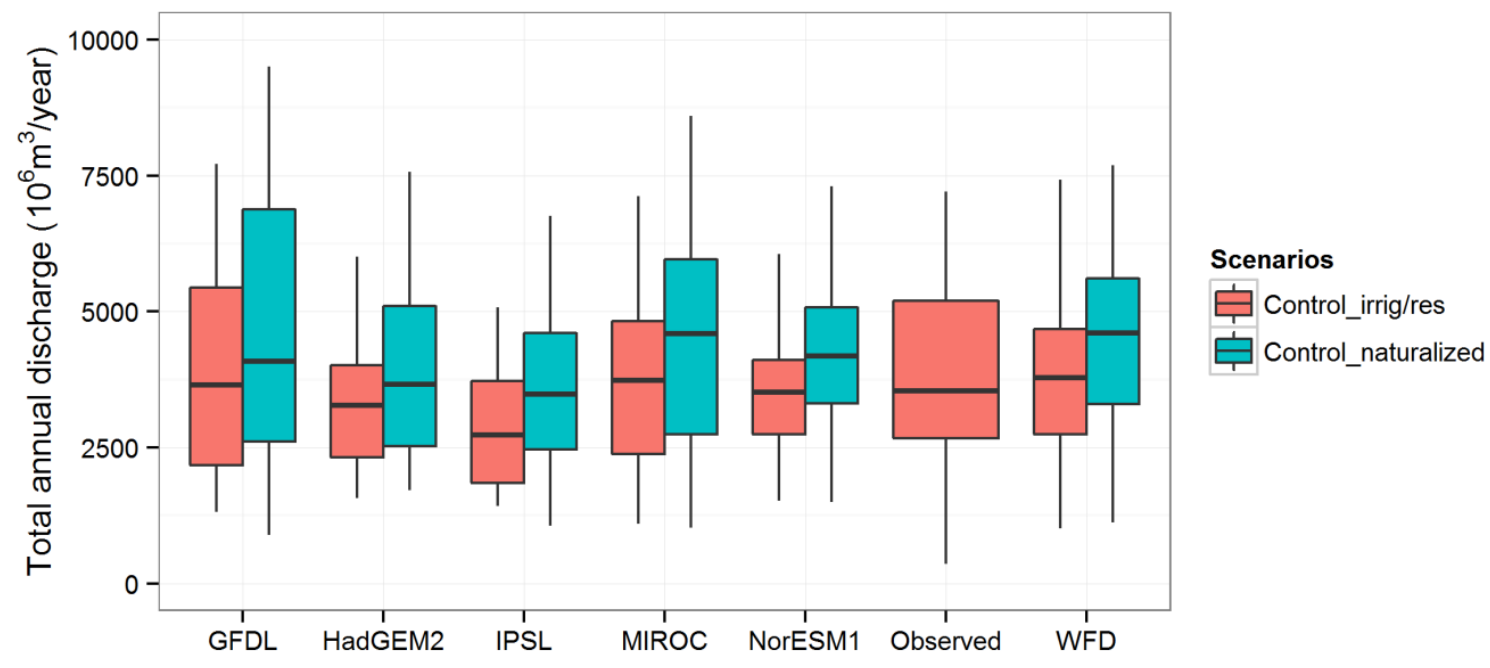

Figure 3 Boxplot of simulated annual inflow for five GCMs and WFD compared with observed values for control period

(1971-2000). The boxes illustrate the 25th, 50th, and 75th percentiles of the ensemble. The whiskers represent the total

sample spread.

\subsection{Climate change impacts}

Simulations results showed that climate change is reducing the inflows into the lake during the high flow season, especially in April and June (Figure 4). This is the case for both RCP2.6 and 8.5. However, the decrease in inflow is much higher under RCP 8.5. By mid-century (2040-2069) the mean and peak of the annual cycle of projected naturalized inflow under RCP2.6 is reduced by $10 \%$ and $15 \%$, respectively. These values are $27 \%$ and $38 \%$ for RCP8.5, respectively. In winter (low flow season) the inflow will slightly increase. In addition, the mean annual cycles show two weeks delay in the peak flow for RCP2.6 and one week for RCP8.5. Figure 5 shows that the mean annual naturalized inflow into the lake will be reduced by $13 \%$ for RCP 2.6 and $37 \%$ for RCP 8.5 by the end of the century. Unlike RCP2.6, the reduction in naturalized inflow under RCP8.5 will be significant in early, mid and late century compared to the historical inflow. 

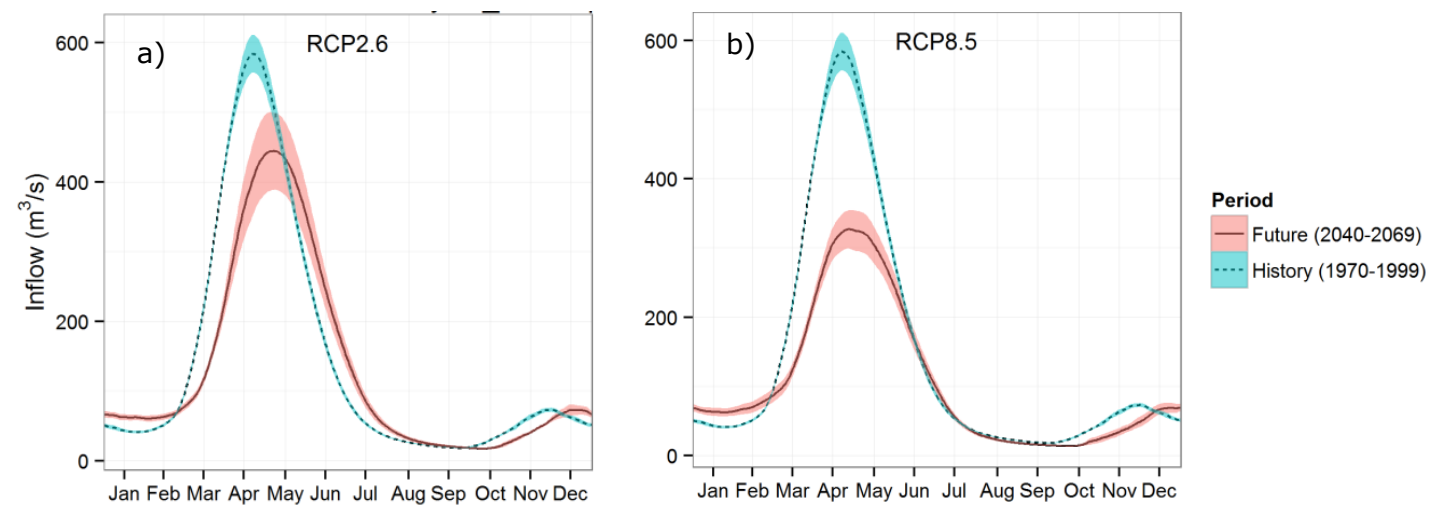

Figure 4 mean annual cycle of projected 30-day moving average of inflow for five GCMs for control period (19712000) and future (2040-2069) under RCP2.6 (a) and RCP8.5 (b). The shadows represent the standard error of the mean for all five GCMs.

\subsection{Impacts of future anthropogenic scenarios}

The results from the control period (1971-2000) showed that the reduction_irrig scenario would have resulted in a 13\% increase in inflow compared to current-irrig/res scenario. While, the expansion_irrig/res scenario would have decreased the inflow by $10 \%$ compared to the currentirrig/res scenario (Figure 5). The results for future climatic conditions showed that the expansion_irrig/res will have a considerable impact on the inflow reduction in the coming century. By the end of century, the expansion_irrig/res scenario will cause a significant decline in the thirty years mean inflow compared to current_irrig/res by $10 \%$ under RCP 2.6 and 12\% under RCP8.5. On the other hand, the reduction_irrig scenario will increase the inflow in next century compared to other water use scenarios. Under RCP2.6, the reducing irrigation scenario will increase significantly the thirty years mean inflow compared to the current_irrig/res by $11 \%$ by the end of century. For RCP8.5 this value is $10 \%$. The reduction_irrig scenario will have a significant impact on inflow under RCP2.6 and not under Rep8.5; while expation_irrig/res will have a significant impact in both RCPs. The uncertainty range increases over time for both RCPs. 

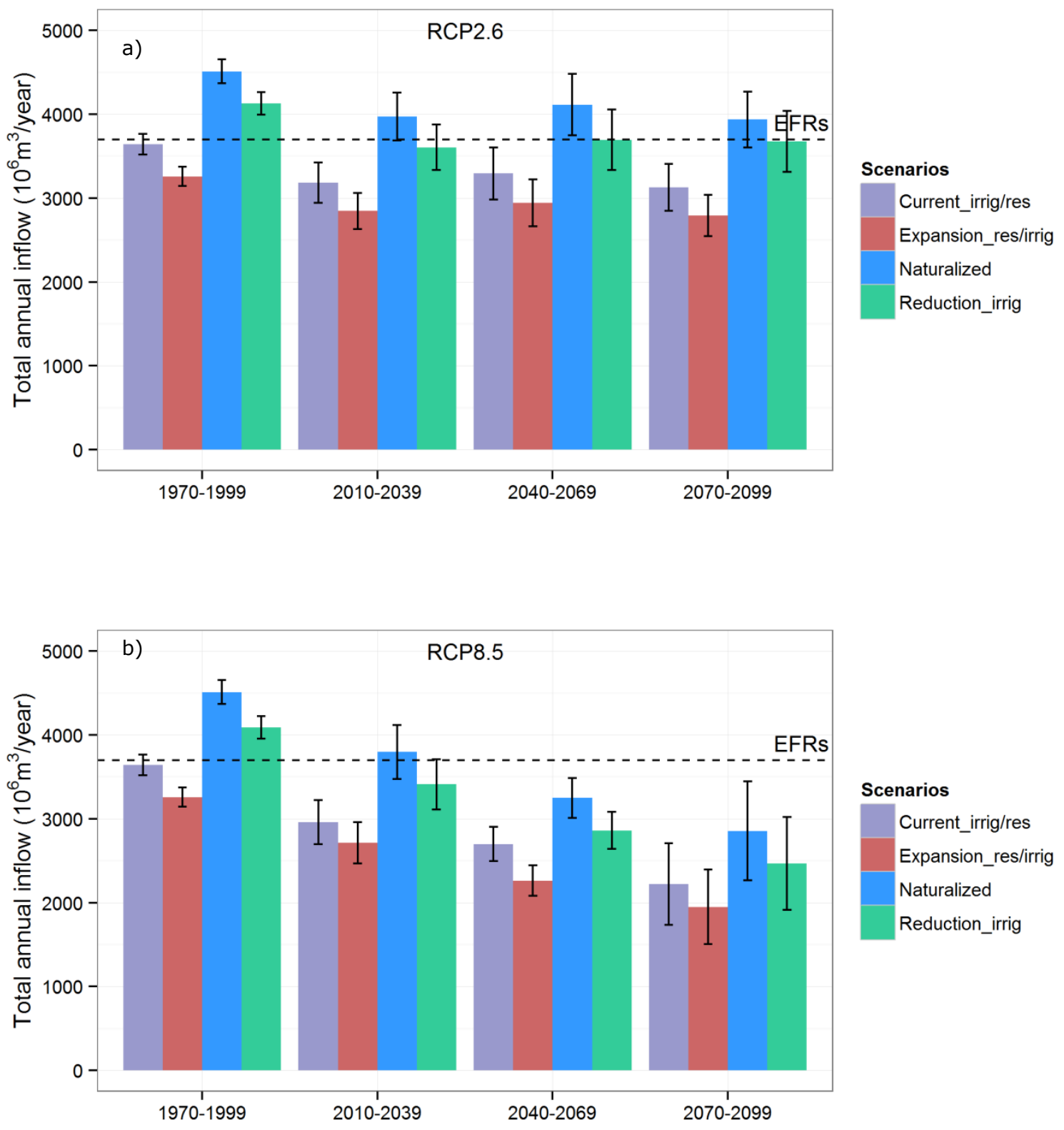

Figure 5 Total average inflow to that lake for the control (1971-2000) and future time slices (2010-2039, 2040-2069 and 2070-2099), for the two different water resources plans under RCP 2.6 (a) and RCP 8.5 (b), compared with EFRs, the error bars represent the standard error of the mean.

\subsection{Fulfilling environmental flow requirements (EFRs)}

The estimated annual and monthly EFRs based on the adopted VMF method are presented in Figure 6. The calculated annual EFRs estimated to be around $3.7 \cdot 10^{9} \mathrm{~m}^{3}$. Simulation results indicated that for the control period the EFRs would have met for all scenarios except expation_irrig/res.

Under RCP2.6, the naturalized and the reduction-irrig scenarios inflows on average resulted in sufficient flows to sustain EFRs. However, this was not the case for current_irrig/res and expansion_irrig/res scenarios where the deficit will be around 15\%, 24\% by end-century, respectively. Under RCP8.5, all water use scenarios will result in inflow well below the EFRs in the whole century. The deficit would be $23 \%, 33 \%, 39 \%$ and $47 \%$ for naturalized, reduction_irrig, current_irrig/res and expansion_irrig/res scenarios by the end of century, respectively. 
Figure 6 shows the monthly predicted EFR deficit for the lake for mid-century (2040-2069). Regardless the climate and water management scenarios, the lake will be in the highest deficit from April to June. From July to November the lake will meet the EFRs, but small inflow deficits are projected for December- March. Overall, the EFR deficits are stronger for RCP8.5 than 2.6.

\begin{tabular}{llllllllllllll}
\hline & Jan & Feb & Mar & Apr & May & Jun & Jul & Aug & Sep & Oct & Nov & Dec & Annual \\
\hline EFRs $\left(\times \mathbf{1 0}^{\mathbf{6}} \mathbf{m}^{\mathbf{3}}\right)$ & 204 & 181 & 257 & 534 & 1108 & 611 & 270 & 115 & 62 & 42 & 128 & 185 & 3700 \\
\hline
\end{tabular}

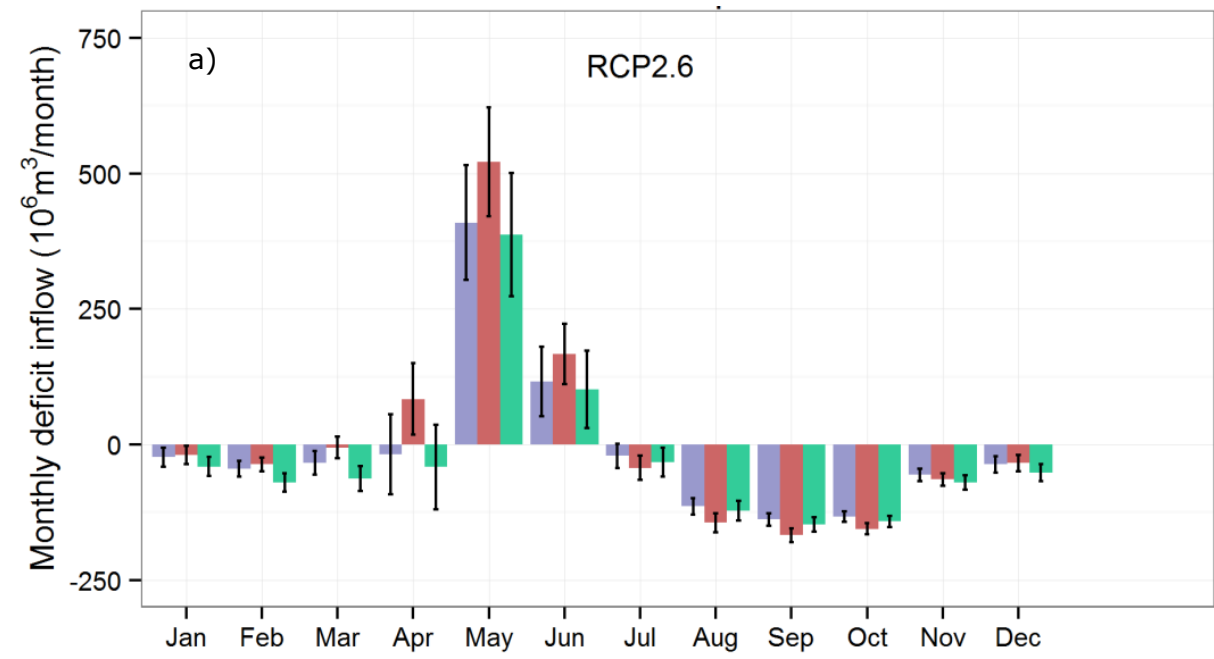

\section{Scenarios}

Current-res/irrig

Expand-res/irrig

Limit-res/irrig

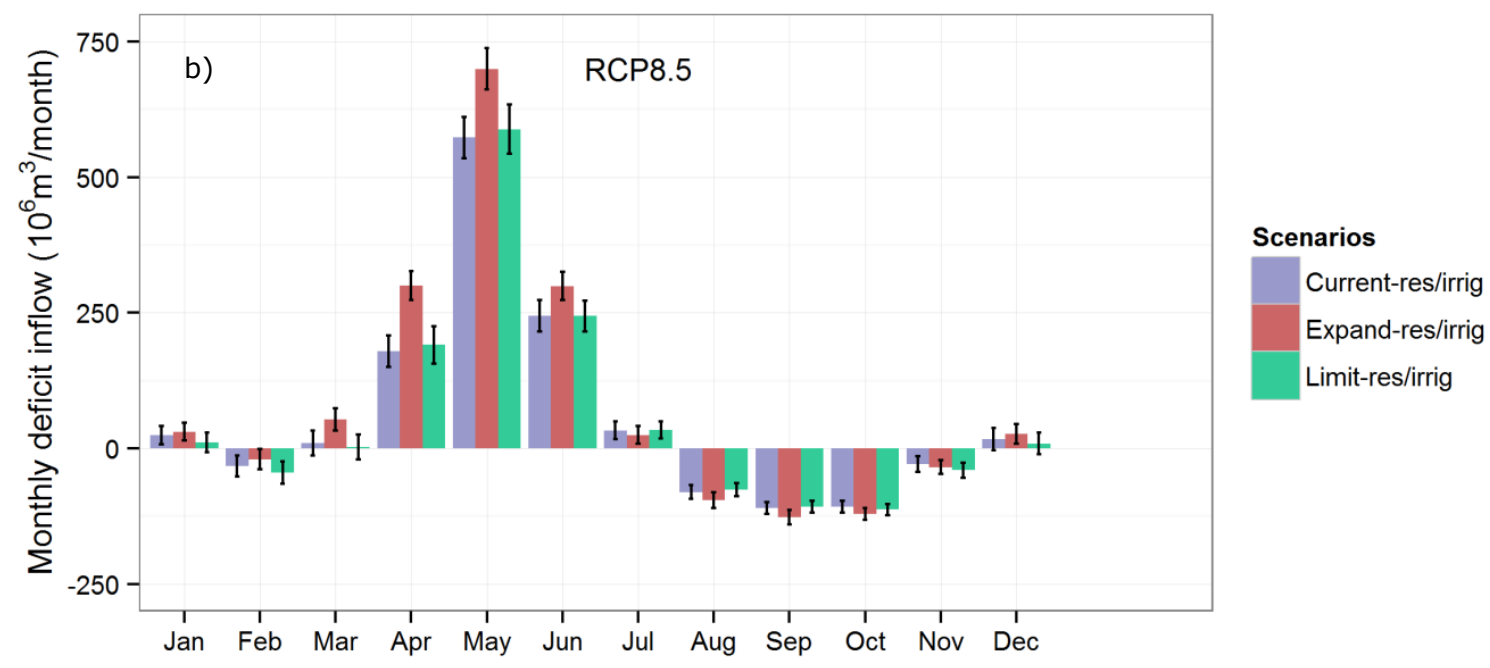

Figure 6 The monthly environmental flow requirements (EFRs) (table) and the monthly average of projected inflow for mid-century (2041-2070) deficit for different water resources plan under RCP 2.6 (a) and RCP 8.5 (b), the error bars represent the standard error of the mean. 


\section{Discussion}

Urmia Lake, the world second largest hypersaline lake and a highly vulnerable ecosystem has been desiccated over the last two decades resulting in severe socio-environmental consequences. To assess whether future water resources management plans allocate enough water to preserve the lake ecosystem, we first needed to define minimum environmental flow requirements (EFRs) for this hypersaline lake. The selection of EFRs method is a crucial step in the methodology of this article. Most ecological flow methods focus on the vulnerability of the lake, but ignore the extra protection during dry months. It may cause underestimations in the result. By selecting a hydrological approach and classifying flow regimes, we were able to increase the protection for low-flow months by allocating more flow. We estimated the annual EFRs to be about $3.7 \cdot 10^{9} \mathrm{~m}^{3}$ which is higher than a previous study by Abbaspour and Nazaridoust (2007) who estimated ecological EFRs to be $3.08 \cdot 10^{9}$ $\mathrm{m}^{3}$. Their EFR estimation was based on calculating inflow applying the difference between the lake evaporation and precipitation (E-P) on their estimated ecological lake surface $\left(4.6 \cdot 10^{9} \mathrm{~m}^{2}\right)$. However, recent observations indicated that the lake (E-P) have increased in the last few years (Lake Urmia restoration programme 2014) which will increase their environmental flow estimations. In addition, we allocated higher flows for EFRs for dry months to increase the protection of the lake, which can also be the reason of higher estimation of EFRs in this study.

Our results from the control period (1971-2000) indicated that without climate change, the inflow would have been sufficient to meet the lake EFRs for all water resources scenarios. Salt lakes, hypersaline lakes in particular, are so sensitive to any minor changes in any component of their hydrological budgets, especially evaporation (Williams 2002). Therefore, it is not surprising that the lake responses quickly to any changes in climate. The historical studies about Urmia lake also highlighted the substantial role of climate change in the lake desiccation (Fathian et al. 2014, Hassanzadeh 2010).

The results clearly showed the significant impact of climate change on annual inflow to the lake under RCP8.5. This impact is not significant under RCP2.6 (figure 5). These results are consistent with the IPCC report which showed a decline in runoff for this region for both near-term (Kirtman 2013) and long-term future (Collins 2013) under the rapid greenhouse-gas concentration scenarios. However, under both RCPs climate change will reduce the water availability in the basin especially in the wet season. This is an important result as the basin already has a serious challenge to secure water availability. IPCC also reported a projected decline in future precipitation for the same period (March till August) for this region (Kirtman 2013). Our results also showed that the peak river flow will be shifted to later in the year which could be caused by a longer period of snow melt.

Our results indicated that if future climate change is limited due to rapid mitigation measures (RCP2.6) inflow can just meet the EFRs for the limited irrigation management plan. In this case implementing the limited irrigation plan should be the first priority. However, this is not the case for the high/rapid concentration scenario also other water resources plans. Under more rapid climate change scenarios (RCP8.5) limited irrigation might be effective in short-term, but would be insufficient in the long-term, so more drastic measures are needed. In general, the impacts of different water resources strategies were more visible under the low concentration scenario (RCP2.6) than under the high concentration scenario (RCP8.5), showing that the dominate impact of climate change in this scenario.

The models result could be affected by different uncertainties. First of all due to significant biases in forcing data simulated by GCMs, we used bias corrected data as input to the VIC model. The statistics for simulated discharge for the control simulations of the GCMs generally correspond well with the simulations based on the WFD dataset and observed values (figure 3). This shows that the bias correction method was successful in eliminating the main bias. Haddeland et al. (2014) used the same data set of bias-corrected GCMs output to force the same model (VIC-irrigation and reservoir model) and their results correspond well with the control period. To include uncertainties in future climate forcing data in particularly regarding future precipitation, we used five different GCMs. Although the 
models differed in the projected changes most models indicated a clear drying trend. However, the use of a larger number of GCMs outputs would better represent the structural uncertainty in climate models (Tebaldi and Knutti 2007).

Secondly, the spatial resolution of the simulation could make some uncertainties in the simulation. Nevertheless, the VIC model was able to simulate the observed streamflow realistically (figure 3 ). It was not possible to develop a forcing data set at finer resolution for all required forcing variables (precipitation, minimum and maximum temperature and wind speed) due to limited availability of observations. However, Shadkam et al. (under revision) included more detailed local information of elevation, soil, land use, irrigation patterns and reservoirs of Urmai's basin during calibration and improved the quality of simulated total nflow which showed a good match with the observed values.

In addition, we focused our simulation on the use of surface water although a part of the irrigated water use in the basin originates from groundwater. Model simulations did not explicitly include groundwater and this could affect our results. However, the simulated streamflow in VIC model is the result of water balance calculations on land surfaces, which includes the shallow rechargeable groundwater through base flow. Therefore, withdrawal from the shallow groundwater below the recharge rate is implicitly included in the simulations. Nevertheless, this does not apply to deep nonrenewable groundwater; hence the simulated availability of water might be slightly underestimated in the simulation (Hanasaki et al. 2008). However, recently, water withdrawn from deep groundwater has been banned in Urmia and this uncertainty is therefore probably small for future simulations.

\section{Conclusions and future outlook}

In this study we assessed how water resources plans can fulfil Urmia lake inflow requirements under different climate change scenarios. The results showed that the water resources plans are not robust to strong changes in climate. In other words, if future climate change is limited due to rapid mitigation measures (RCP2.6) the new strategy, reduction of irrigation water use, can help to preserve the lake. However, it is not the case for higher climate scenario. Therefore, regarding a drier future and increasing water demand in the region, an urgent action in both regional (to limit anthropogenic impact) and global scale (to limit greenhouse-gas concentration) is needed to save the lake. As RCP2.6 is a relatively optimistic scenario, we recommend investing in other adaptation options to increase the inflow to lake. Examples of adaptation measures could be interbasin water transfer, reducing irrigation water requirement by changing crop patterns and using wastewater for irrigation (Lake Urmia restoration programme 2014). In addition, the highest EFRs deficit will be from April to June. Therefore an integrated water management plan, emphasizing seasonal water management, could play a role to sustain the lake. Another option can be to restore the lake partially by reducing the surface area of the lake (and reduce evaporation loss) until more water will become available (UNDP 2014). The plan should be tailored to the various stages of climate change impacts and water availability conditions and should include balancing demands for irrigation, ecosystem preservation, social and human impacts as well as operating within the national and regional political realities. Furthermore, since already $80 \%$ of the lake has been desiccated, it is possible that lake will dry up completely in case of rapid global warming. Therefore it is recommended to assess also an adaptation plan in case of drying the lake completely in near future. The results of this study highlight the need for most attention for desiccating saline and hypersaline waterbodies, as one the most earth's vulnerable ecosystem, under future development and climate change. 


\section{Reference}

Abbaspour, M. and Nazaridoust, A. (2007) Determination of environmental water requirements of Lake Urmia, Iran: an ecological approach. International Journal of Environmental Studies, 64(2), pp. 161-169.

AghaKouchak, A., Norouzi, H., Madani, K., Mirchi, A., Azarderakhsh, M., Nazemi, A., Nasrollahi, N., Farahmand, A., Mehran, A. and Hasanzadeh, E. (2015) Aral Sea syndrome desiccates Lake Urmia: Call for action. Journal of Great Lakes Research, 41(1), pp. 307-311.

Allen, R. G., Pereira, L. S., Raes, D. and Smith, M. (1998) Crop evapotranspirationGuidelines for computing crop water requirements-FAO Irrigation and drainage paper 56. FAO, Rome, 300(9).

Asem, A., Mohebbi, F. and Ahmadi, R. (2012) Drought in Urmia Lake, the largest natural habitat of brine shrimp Artemia. World Aquaculture, 43(1), pp. 36-38.

Biemans, H., Haddeland, I., Kabat, P, Ludwig, F., Hutjes, R., Heinke, J., Von Bloh, W. and Gerten, D. (2011) Impact of reservoirs on river discharge and irrigation water supply during the 20th century. Water Resources Research, 47(3), pp. W03509.

Collins, M., R. Knutti, J. Arblaster, J.-L. Dufresne, T. Fichefet, P. Friedlingstein, X. Gao, W.J. Gutowski, T. Johns, G. Krinner, M. Shongwe, C. Tebaldi, A.J. Weaver and M. Wehner (2013) Long-term climate change: projections, commitments and irreversibility. Cambridge University Press, Cambridge, United Kingdom and New York, NY, USA.

Delju, A., Ceylan, A., Piguet, E. and Rebetez, M. (2013) Observed climate variability and change in Urmia Lake Basin, Iran. Theoretical and Applied Climatology, 111(1-2), pp. 285-296.

Eimanifar, A. and Mohebbi, F. (2007) Urmia Lake (northwest Iran): a brief review. Saline Systems, 3(5), pp. 1-8.

Fathian, F., Morid, S. and Kahya, E. (2014) Identification of trends in hydrological and climatic variables in Urmia Lake basin, Iran. Theoretical and Applied Climatology, pp. $1-22$.

Golabian, H. (2011) Urumia Lake: Hydro-ecological stabilization and permanence. in Macro-engineering Seawater in Unique Environments: Springer. pp. 365-397.

Haddeland, I. (2006) Anthropogenic impacts on the continental water cycle. Unpublished Dissertation, University of Oslo.

Haddeland, I., Heinke, J., Biemans, H., Eisner, S., Flörke, M., Hanasaki, N., Konzmann, M., Ludwig, F., Masaki, Y. and Schewe, J. (2014) Global water resources affected by human interventions and climate change. Proceedings of the National Academy of Sciences, 111(9), pp. 3251-3256.

Haddeland, I., Skaugen, T. and Lettenmaier, D. (2007) Hydrologic effects of land and water management in North America and Asia. Hydrology and Earth System Sciences, 11(2), pp. 1035-1045.

Haddeland, I., Skaugen, T. and Lettenmaier, D. P. (2006) Anthropogenic impacts on continental surface water fluxes. Geophysical Research Letters, 33(8). 
Hammer, U. T. (1986) Saline lake ecosystems of the world, Springer Science \& Business Media.

Hamzekhani, F. G., Saghafian, B. and Araghinejad, S. (2015) Environmental management in Urmia Lake: thresholds approach. International Journal of Water Resources Development, (ahead-of-print), pp. 1-12.

Hassanzadeh, E. (2010) Determining the Effect of Constructing Hydraulic Structureson Declining the Urmia Lake Level. Unpublished Dissertation, Tabriz University.

Hassanzadeh, E., Zarghami, M. and Hassanzadeh, Y. (2012) Determining the main factors in declining the Urmia Lake level by using system dynamics modeling. Water Resources Management, 26(1), pp. 129-145.

Hempel, S., Frieler, K., Warszawski, L., Schewe, J. and Piontek, F. (2013) A trend-preserving bias correction-the ISI-MIP approach. Earth System Dynamics, 4(2), pp. 219-236.

Henareh, K. A., Mayer, A. L. and Norman, E. S. (2014) Water Flows Toward Power: Socioecological Degradation of Lake Urmia, Iran. Society \& Natural Resources, 27(7), pp. 759-767.

Hurkmans, R., De Moel, H., Aerts, J. and Troch, P. (2008) Water balance versus land surface model in the simulation of Rhine river discharges. Water Resources Research, 44(1).

Iran Ministry of Energy, Deputy of water and wastewater, Macro Planning Bureau (2014) The National Water Master Plan Study in the Aras, Sefidrood, between Sefidrood and Haraz, Atrac and Urmia: Agricultural Water Use Study in Urmia Lake Basin, Report Number: 2385070-4420-19464.

ISI-MIP Available: isi-mip.org.

Jalili, S., Hamidi, S. A. and Ghanbari, R. N. (2015) Climate variability and anthropogenic effects on Lake Urmia water level fluctuations, northwestern Iran. Hydrological sciences journal.

Karbassi, A., Bidhendi, G. N., Pejman, A. and Bidhendi, M. E. (2010) Environmental impacts of desalination on the ecology of Lake Urmia. Journal of Great Lakes Research, 36(3), pp. 419-424.

Kirtman, B., S.B. Power, J.A. Adedoyin, G.J. Boer, R. Bojariu, I. Camilloni, F.J. DoblasReyes, A.M. Fiore, M. Kimoto, G.A. Meehl, M. Prather, A. Sarr, C. Schär, R. Sutton, G.J. van Oldenborgh, G. Vecchi and H.J. Wang (2013) Near-term Climate Change: Projections and Predictability. Climate Change 2013: The Physical Science Basis. Contribution of Working Group I to the Fifth Assessment Report of the Intergovernmental Panel on Climate Change

T.F., D. Qin, G.-K. Plattner, M. Tignor, S.K. Allen, J. Boschung, A. Nauels, Y. Xia, V. Bex and P.M. Midgley (eds.)]. . Cambridge University Press, Cambridge, United Kingdom and New York, NY, USA.

Lake Urmia restoration programme (2014) Lake Urmia restoration plan. The summary report till May 2014.

Liang, X., Lettenmaier, D. P., Wood, E. F. and Burges, S. J. (1994) A simple hydrologically based model of land surface water and energy fluxes for general circulation models. Journal of Geophysical Research: Atmospheres (1984-2012), 99(D7), pp. 1441514428. 
Lohmann, D., Raschke, E., Nijssen, B. and Lettenmaier, D. (1998a) Regional scale hydrology: I. Formulation of the VIC-2L model coupled to a routing model. Hydrological sciences journal, 43(1), pp. 131-141.

Lohmann, D., Raschke, E., Nijssen, B. and Lettenmaier, D. (1998b) Regional scale hydrology: II. Application of the VIC-2L model to the Weser River, Germany. Hydrological sciences journal, 43(1), pp. 143-158.

Meijer, K., van der Krogt, W. and van Beek, E. (2012) A new approach to incorporating environmental flow requirements in water allocation modeling. Water Resources Management, 26(5), pp. 1271-1286.

Moss, R. H., Edmonds, J. A., Hibbard, K. A., Manning, M. R., Rose, S. K., Van Vuuren, D. P., Carter, T. R., Emori, S., Kainuma, M. and Kram, T. (2010) The next generation of scenarios for climate change research and assessment. Nature, 463(7282), pp. 747756.

Nijssen, B., Lettenmaier, D. P., Liang, X., Wetzel, S. W. and Wood, E. F. (1997) Streamflow simulation for continental-scale river basins. Water Resources Research, 33(4), pp. 711-724.

Nijssen, B., O'Donnell, G. M., Lettenmaier, D. P., Lohmann, D. and Wood, E. F. (2001a) Predicting the discharge of global rivers. Journal of Climate, 14(15), pp. 3307-3323.

Nijssen, B., Schnur, R. and Lettenmaier, D. P. (2001b) Global retrospective estimation of soil moisture using the variable infiltration capacity land surface model, 1980-93. Journal of Climate, 14(8), pp. 1790-1808.

Piani, C., Weedon, G., Best, M., Gomes, S., Viterbo, P., Hagemann, S. and Haerter, J. (2010) Statistical bias correction of global simulated daily precipitation and temperature for the application of hydrological models. Journal of Hydrology, 395(3), pp. 199-215.

RadioFarda (2014) Urmia Representative in the Parlemant: 50 villages around Urmia lake have been evacuated

Riahi, K., Rao, S., Krey, V., Cho, C., Chirkov, V., Fischer, G., Kindermann, G., Nakicenovic, N. and Rafaj, P. (2011) RCP 8.5-A scenario of comparatively high greenhouse gas emissions. Climatic Change, 109(1-2), pp. 33-57.

Rokni, K., Ahmad, A., Solaimani, K. and Hazini, S. (2015) A new approach for surface water change detection: Integration of pixel level image fusion and image classification techniques. International Journal of Applied Earth Observation and Geoinformation, 34 , pp. 226-234.

Shadkam, S., Ludwig, F., Oel, P., Kirmit, C. and Kabat, P. (under revision) Impacts of Climate Change and Water Resources Development on the Declining Inflow into Iran's Urmia Lake Journal of Great Lakes Research.

Smakhtin, V., Revenga, C. and Döll, P. (2004) A pilot global assessment of environmental water requirements and scarcity. Water International, 29(3), pp. 307-317.

Smakhtin, V. U., Shilpakar, R. and Hughes, D. (2006) Hydrology-based assessment of environmental flows: an example from Nepal. Hydrological sciences journal, 51(2), pp. 207-222.

Tabari, H., Nikbakht, J. and Talaee, P. H. (2013) Hydrological drought assessment in Northwestern Iran based on streamflow drought index (SDI). Water Resources Management, 27(1), pp. 137-151. 
Taylor, K. E., Stouffer, R. J. and Meehl, G. A. (2012) An overview of CMIP5 and the experiment design. Bulletin of the American Meteorological Society, 93(4), pp. 485498.

Tebaldi, C. and Knutti, R. (2007) The use of the multi-model ensemble in probabilistic climate projections. Philosophical Transactions of the Royal Society A: Mathematical, Physical and Engineering Sciences, 365(1857), pp. 2053-2075.

Tennant, D. L. (1976) Instream flow regimens for fish, wildlife, recreation and related environmental resources. Fisheries, 1(4), pp. 6-10.

Tessmann, S. (1980) Environmental Assessment, Technical Appendix E in Environmental Use Sector Reconnaissance Elements of the western Dakotas Region of South Dakota study. Water Resources Research Institute, South Dakota State University.

Torabian, E. (2015) Exploring social vulnerability and environmental migration in Urmia Lake in Iran: Comparative insights from the Aral Sea. in The State of Environmental Migration International Organization for Migration (IOM).

UNDP, Iran Department of Environment, (2014) Towards a solution for Iran's drying wetlands.

UNEP, Global Environmental Alert Sercice, (2012) The Drying of Iran's Lake Urmia and its Environmental Consequences: http://na.unep.net/geas/getUNEPPageWithArticleIDScript.php?article_id=79.

Van Vuuren, D. P., Stehfest, E., den Elzen, M. G., Kram, T., van Vliet, J., Deetman, S., Isaac, M., Goldewijk, K. K., Hof, A. and Beltran, A. M. (2011) RCP2. 6: exploring the possibility to keep global mean temperature increase below 2 C. Climatic Change, 109(1-2), pp. 95-116.

Vliet, M. v., Franssen, W. H., Yearsley, J. R., Ludwig, F., Haddeland, I., Lettenmaier, D. P. and Kabat, P. (2013) Global river discharge and water temperature under climate change. Global Environmental Change.

Vliet, M. v., Yearsley, J. R., Ludwig, F., Vögele, S., Lettenmaier, D. P. and Kabat, P. (2012) Vulnerability of US and European electricity supply to climate change. Nature Climate Change, 2(9), pp. 676-681.

Vrugt, J. A., Gupta, H. V., Bouten, W. and Sorooshian, S. (2003) A Shuffled Complex Evolution Metropolis algorithm for optimization and uncertainty assessment of hydrologic model parameters. Water Resources Research, 39(8).

Warszawski, L., Frieler, K., Huber, V., Piontek, F., Serdeczny, O. and Schewe, J. (2014) The Inter-Sectoral Impact Model Intercomparison Project (ISI-MIP): Project framework. Proceedings of the National Academy of Sciences, 111(9), pp. 3228-3232.

Weedon, G., Gomes, S, Viterbo, P ,Shuttleworth, WJ, Blyth, E, Österle, H, Adam, JC, Bellouin, N, Boucher, O, Best, M (2011) Creation of the WATCH Forcing Data and Its Use to Assess Global and Regional Reference Crop Evaporation over Land during the Twentieth Century. Journal of Hydrometeorology, 12(5).

Williams, W. D. (2002) Environmental threats to salt lakes and the likely status of inland saline ecosystems in 2025. Environmental Conservation, 29(02), pp. 154-167.

Wu, Z., Lu, G., Wen, L., Lin, C. A., Zhang, J. and Yang, Y. (2007) Thirty-five year (19712005) simulation of daily soil moisture using the variable infiltration capacity model over China. Atmosphere-Ocean, 45(1), pp. 37-45. 
Xie, Z., Yuan, F., Duan, Q., Zheng, J., Liang, M. and Chen, F. (2007) Regional parameter estimation of the VIC land surface model: Methodology and application to river basins in China. Journal of Hydrometeorology, 8(3), pp. 447-468. 


\section{Supplementary information}

\section{S1)}

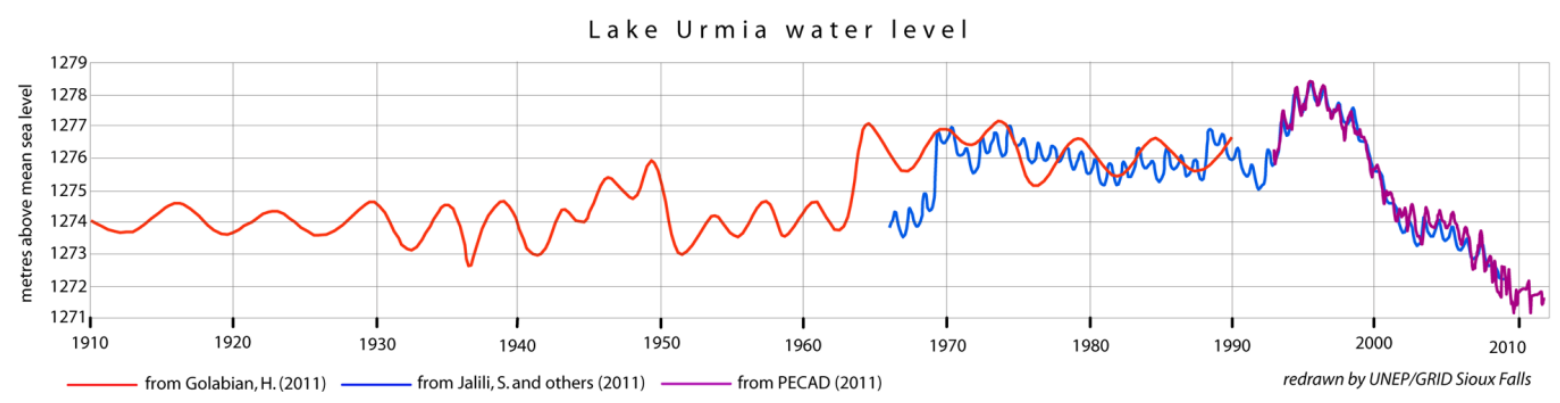

Overlaying multiple records of the lake's surface elevation (UNEP 2012) 
S2)

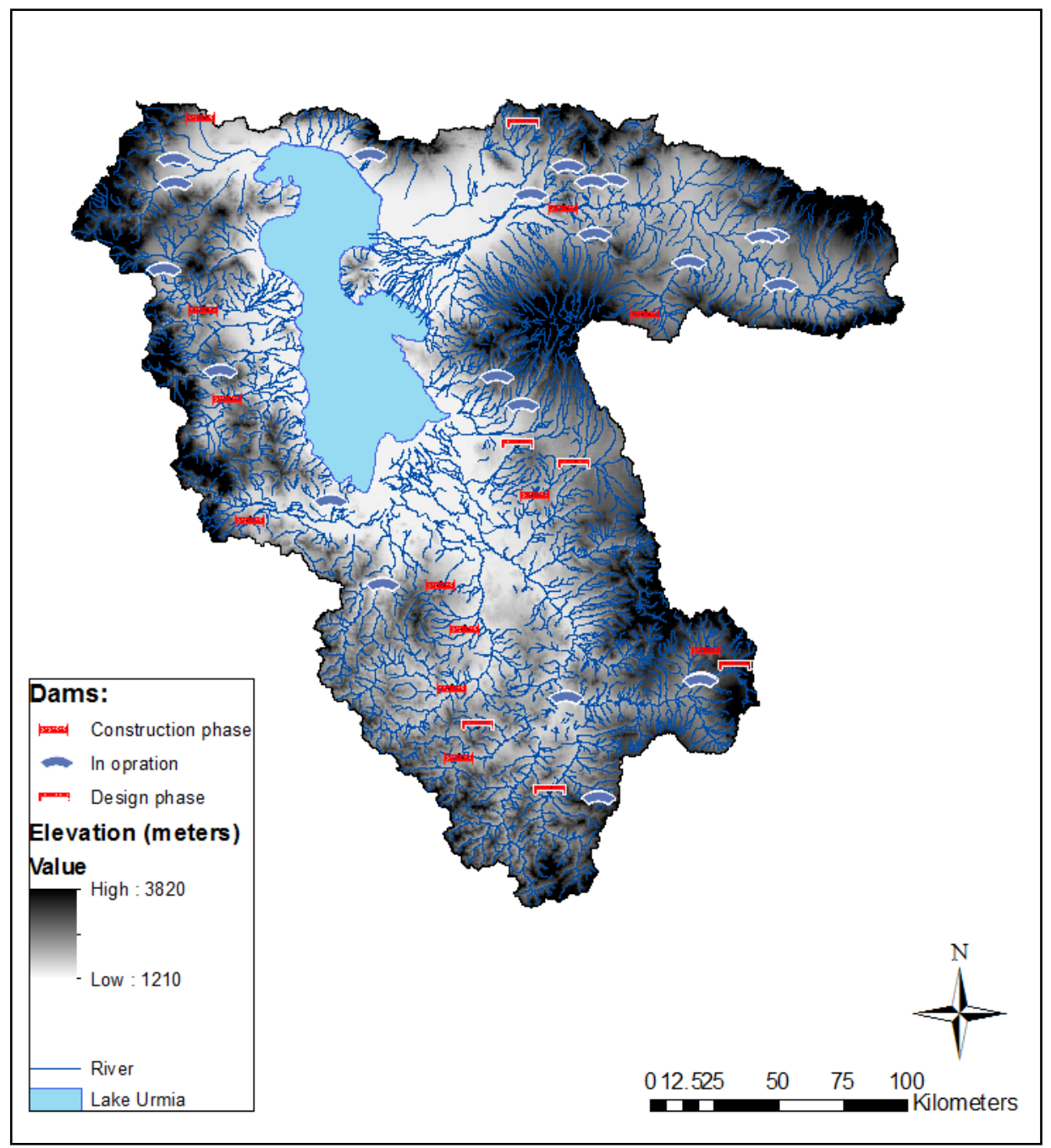

Urmia basin and the location of the main current and future dams (Source of information: Iran Ministry of Energy, Deputy of water and wastewater, Macro Planning Bureau) 

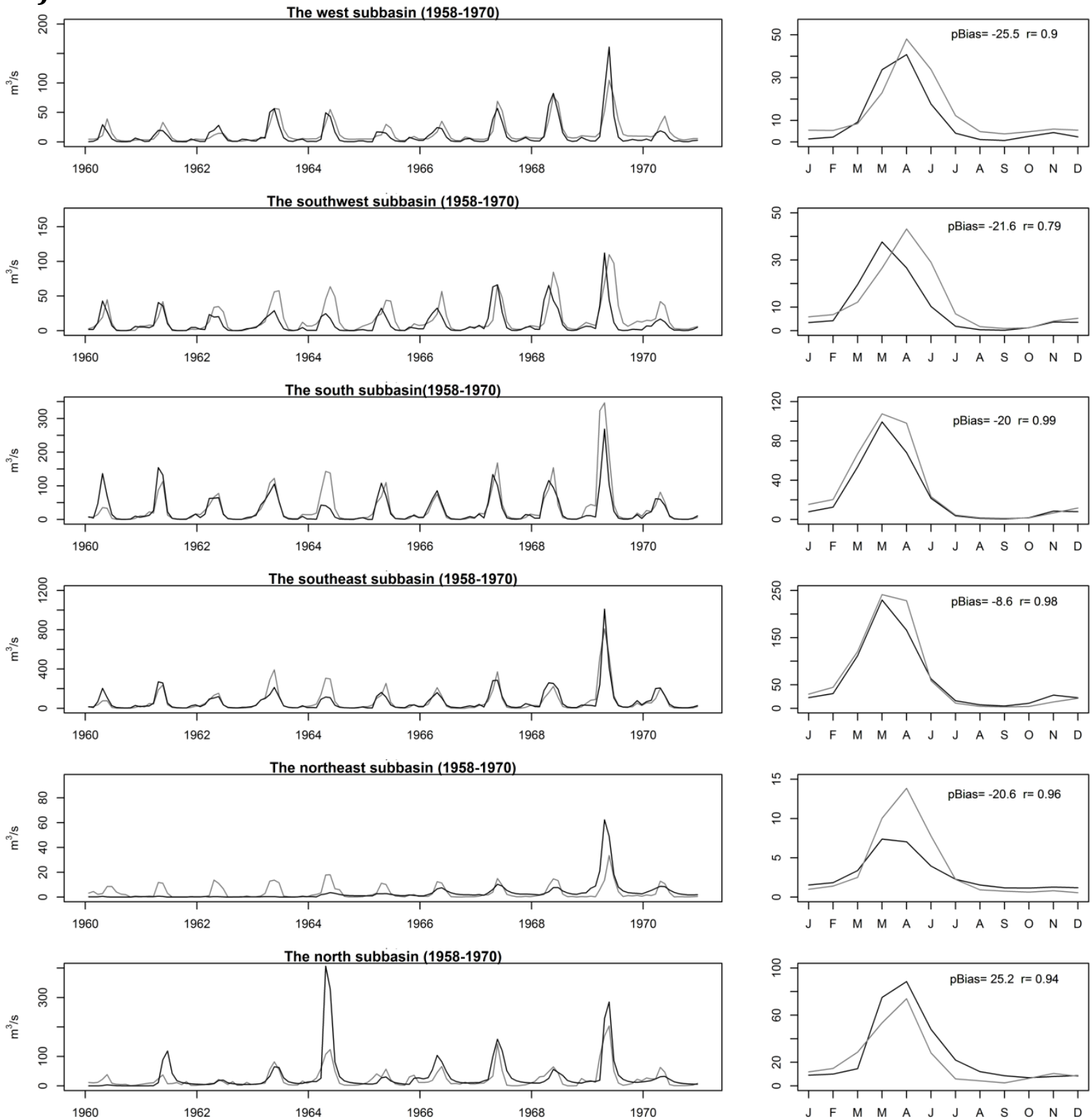

Calibration results for monthly time series and mean annual cycles of observed and simulated streamflow data for all six subbasins of Urmia basin (Shadkam et al., under revision) 